\title{
DESTRUCTIVE EVOLUTION OF POSTMELIORATED LANDSCAPES OF CENTRAL MESCHERA
}

\author{
TATIANA KHARITONOVA
}

Moscow Lomonosov State University, email: kharito@m9com.ru

Received: $2^{\text {nd }}$ March 2011, Accepted: $24^{\text {th }}$ November 2011

\section{INTRODUCTION}

Nowadays in Russia, due to the depressive state of landscape-oriented economic sector agriculture and forestry - we observe the process of mass abandonment of cultivated land. Small part of abandoned territory changes the type of land use to settlement or recreational, greater part starts functioning and evolving in natural mode. Prediction of abandoned landscapes trend of evolution is a requisite base of optimal landscape and socio-economic planning.

In the article we analyze the plentiful material of 33-year functioning of the Vozha catchment cultural landscape (Central Meschera), obtained by the group of Moscow university chair of Physical Geography and Landscape Studies. During the observation period, three phases of socio-economic development of the territory were seen: 1966-1985 - extensive arable and pasture farming with self-flowing drainage; 1986-1993 - intensive agriculture with draining-irrigation system supplied by locks and pumping station; 1993 2010 - fields abandonment, closedown of pumping station, channels clogging and soiling.

Main goal of this work was to compare the function of landscape under various anthropogenic pressures and estimation of the degradation of the Vozha catchment cultural landscape. Cultural landscape is understood as a landscape purposely modified by man to effectively meet its socio-economic functions - resource-reproductive, environmental, nature conservation, aesthetic and educational (Наука 1989). Used classification of landscape socio-economic functions is similar to adopted in Europe classification of ecosystem services - provisioning, regulating, supporting and cultural function (Millennium Ecosystem Assessment 2005). Estimation was carried out under the following criteria:

- Biological production, a characteristic of reproductive function, valued by harvests in meadow sites and by timber increment in forested geosystems

- Swamping process, a characteristic of environmental function, valued by soil moisture content and bio-indication.

- Soil fertility, a characteristic of nature conservation and reproductive functions, valued by humus and nitrogen content, $\mathrm{pH}$ and bio-indication.

This article discloses only results of investigation which concerns meadow sites dynamics.

\section{SITE RECOGNITION}

The research was held in central Meschera lowland, within lake and outwash plains (Fig.1). This is mostly lowered part of Meschera, its true altitudes are 110-125 meters, so it 
accumulates the flow from adjacent territory and even in dry years it's well supported by ground water. Annual precipitation, $620 \mathrm{~mm}$ in average, considerably varies from year to year within the range 400 to $850 \mathrm{~mm}$. Average January temperature is $-11,1^{\circ} \mathrm{C}$, July $+18,3^{\circ} \mathrm{C}$, aggregated active $\left(>10^{\circ} \mathrm{C}\right)$ temperatures are $2200-2500^{\circ} \mathrm{C}$. In research area predominate two main types of geosystems (Анненская, Мамай, Цесельчук 1990). Outwash geosystems are relatively elevated wavy fresh and damp plains, composed of sand, with Pinus and Picea-Pinus forests on podzolic soils. Lake geosystems are low flat wetlands, composed of peat deposed on sand and loamy sediments of Wurm, with mainly grass marshes (Carex acuta, C.rostrata, C.vesicaria, Calamagrostis canescens, Comarum palustre, Naumburgia thyrsiflora) on peaty and peaty-gley soils. The observed Vozha catchment (named after the river basin) is situated within the lake plain and zone of its influence stretches to the adjacent outwash plain.

Fig. 1: Study area (shown within rectangle)

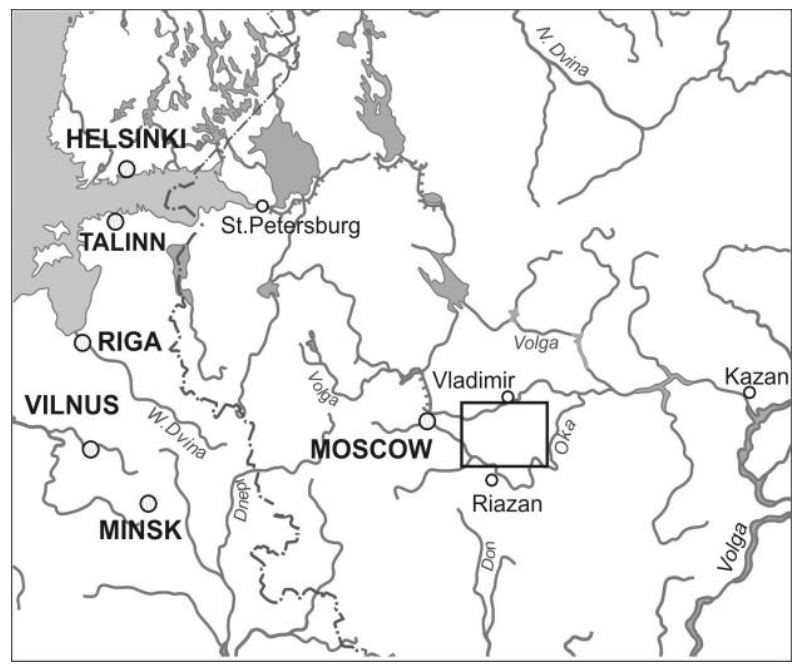

\section{RESEARCH METHODS}

In conditions of changeable moistening, sediments of light composition and therefore of a high filtering coefficient, relief and level of underground water become leading factors of landscape diversification and annual and seasonal dynamics in Meschera (Географические проб. ос. мел. 1990). Therefore the site position in relief was a decisive factor of selection. In the Vozha catchment area, two basic transects were taken perpendicularly to main drainage flow on which the relief leveling, complete landscape description of elementary geosystems forming catena, soil sampling for moisture, $\mathrm{pH}$, organic $\mathrm{C}, \mathrm{N}, \mathrm{P}, \mathrm{K}$ content analysis were performed. As basic transects pass through all variety of geosystems including forested and non-forested, it produces difficulties to analyze biological productivity and moisture relationship. So basic transects were supplemented with five subsidiary short transects crossing only meadow geosystems on four altitude levels which correspond to four degrees of moisture: the lowest level (114-115 m) - marshes and wetlands; low level - wet meadows; middle level - damp meadows and upper level (116-117 m) - fresh meadows. Here flora description with density estimation 
by Drude scale and hay harvesting within two $0,25 \mathrm{~m}^{2}$ sites were conducted annually. Hay harvesting was performed annually during the last 33 years in a period from June 28 to July 2 , at the time when plant ground biomass is greatest in the area. Undoubtedly, this estimate doesn't give us full NPP value, but it is representative in annual dynamics research.

Ecologic ordination of meadow formations by means of L.G. Ramensky ecologic scales (РАМЕНСКИй 1956) was carried out annually. Ramensky methodology which is close to ELLENBERG (2009) consists of accounting ecologic preferences of every species, even rare which contribution to integral habitat value appears to be very important, especially when environment fluctuations are small. According to Ramensky methodology a habitat obtains integral ecologic index which may be considered in following scales. Moistening degree scale: 53-63 dry and fresh meadows; 64-76 damp meadows; 77-88 wet meadows; 89-93 swamp meadows; 94-103 marshes. Moistening variability scale: 5-6 relatively stable moistening; 7-8 middle variable moistening; 9-11 variable. Fertility scale: 1-3 oligotrophic; 4-6 poor; 7-9 limited; 10-13 relatively rich. Ramensky indexes of soil fertility, moistening degree and variability were valued. Series cover period from 1977 to 1984 and from 1998 to 2010 .

Data on ground meadow vegetation harvests and Ramensky indexes were arranged into two classes - representing sites in the zone of drainage influence and in not modified hydrological conditions. Within each class four subclasses were assigned for four taken hypsometric levels. Data were averaged within subclasses and further statistical analysis was conducted over 8 variable types.

\section{RESULTS}

1. Biological productivity dynamics. Among meadow geosystems the highest biomass is produced by indigenous marshes, by middle summer it is up to $2.95 \mathrm{t} / \mathrm{ha}$ dry matter. The lowest productivity is in meadows of upper level with water deficit - at drained upper meadows it is $0,83 \mathrm{t} / \mathrm{ha}$.

Fig. 2: Average production (t/ha) of meadow ecosystems on different elevation level in drained and indigenous conditions. Mean $\pm 0,95$ confidential interval

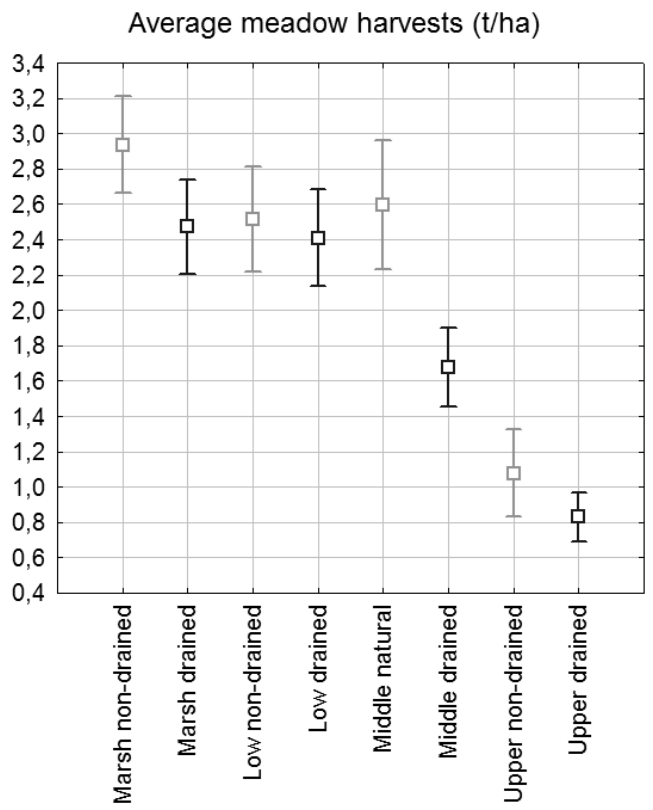


Averaged by 33 years ecosystem productivity displays slight rise of biomass at low level meadows, in other cases drainage results in meadow ecosystems production decrease (Figures 2-3). Zone of positive influence of drainage works on adjacent meadows varies if it is small and falls between 10-20 meters.

The highest loss of productivity took place at middle level meadows, here the difference between drained and non-drained ecosystems production is around $0,8 \mathrm{t} / \mathrm{ha}$, that makes $30 \%$.

Fig. 3: Annual production (t/ha) of meadow ecosystems on different elevation level in drained and non-drained conditions. Polynomial fit.

a. Marshes

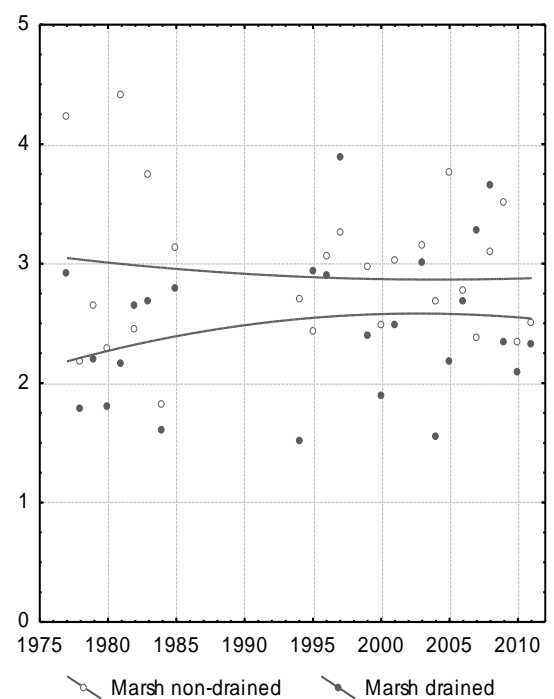

c. Middle level meadows

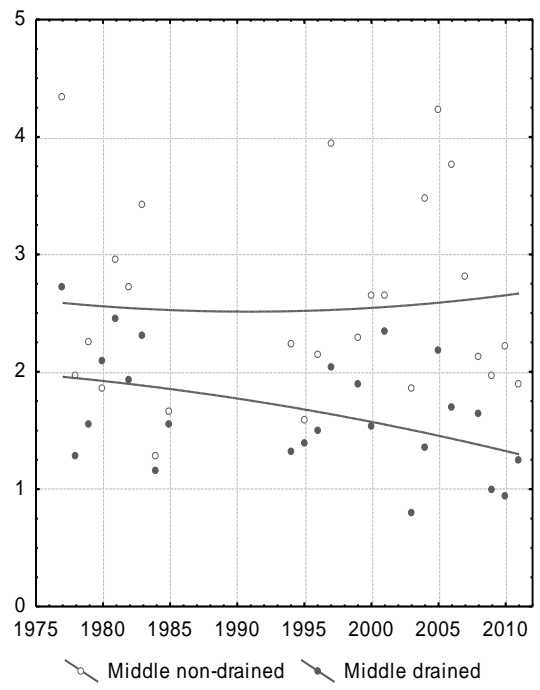

b. Low level meadows

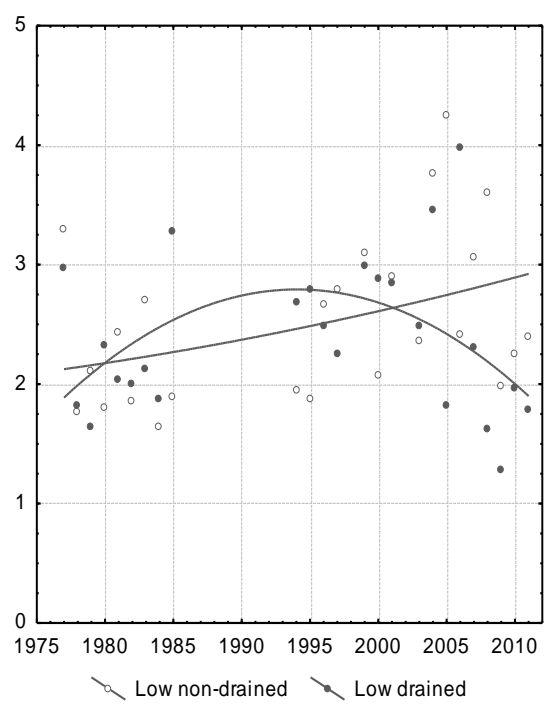

d. Upper level meadows

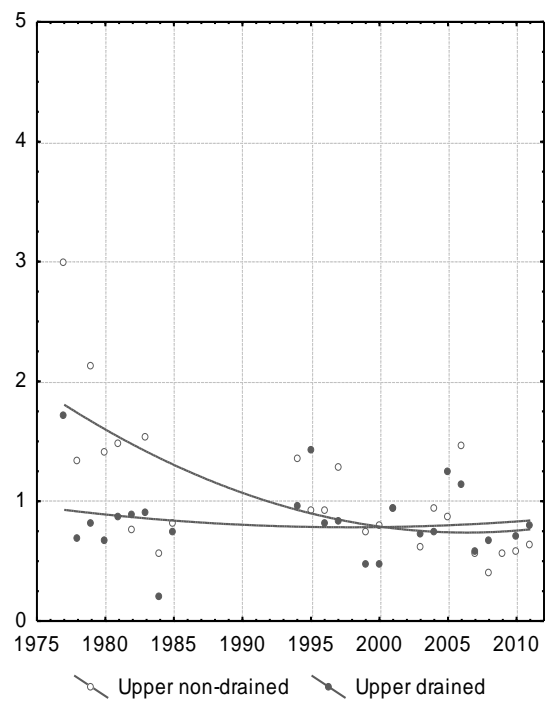


Analysis of productivity in phases of anthropogenic pressure displays slight rise of productivity during period of intensive agriculture with controlled draining-irrigation system and fields fertilizing (Tab. 1).

Table 1: Average meadow harvests taken in period June, 28 - July, 2, t/ha

\begin{tabular}{|c|c|c|c|c|c|c|c|c|}
\hline & \multicolumn{2}{|c|}{ Marshes } & \multicolumn{2}{c|}{ Low level } & \multicolumn{2}{c|}{ Middle level } & \multicolumn{2}{c|}{ Upper level } \\
\cline { 2 - 9 } & Non-drained & Drained & Non-drained & Drained & Non-drained & Drained & Non-drained & Drained \\
\hline $1977-1985$ & 3.01 & 2.29 & 2.17 & 2.23 & 2.51 & 1.89 & 1.45 & 0.87 \\
\hline $1986-1995$ & 2.93 & 2.86 & 2.10 & 2.52 & 2.47 & 1.55 & 1.11 & 1.01 \\
\hline $1996-2010$ & 2.89 & 2.43 & 2.68 & 2.62 & 2.55 & 1.62 & 0.71 & 0.74 \\
\hline mean & $\mathbf{2 . 9 5}$ & $\mathbf{2 . 4 5}$ & $\mathbf{2 . 4 1}$ & $\mathbf{2 . 4 5}$ & $\mathbf{2 . 5 2}$ & $\mathbf{1 . 7 3}$ & $\mathbf{1 . 0 9}$ & $\mathbf{0 . 8 3}$ \\
\hline
\end{tabular}

The rise is evident in drained marsh ecosystems, the main objects of cultivation in the area. Coefficient of variance of meadows productivity is following (Tab. 2) - the highest variations occur at upper level meadows, sensitive to water deficit, while within upper level ecosystems variability is smaller in drained meadows, where it is permanently low, while non-drained meadows in favorable years may produce up to $3.5 \mathrm{t} / \mathrm{ha}$, the typical production of damp and even wet meadows. Low level wet meadows are mostly stable, here the lack of precipitation is compensated by theinflow and underground water, while high precipitation is not overflowing like in the marshes where it results in productivity decrease. Drained marshes fall into low meadows and also give stable, while relatively to natural analogues less, production.

Table 2: Variance of annual meadow harvests

\begin{tabular}{|l|c|c|c|c|c|c|c|c|}
\hline \multirow{2}{*}{} & \multicolumn{2}{|c|}{ Marshes } & \multicolumn{2}{c|}{ Low level } & \multicolumn{2}{c|}{ Middle level } & \multicolumn{2}{c|}{ Upper level } \\
\cline { 2 - 8 } & $\begin{array}{c}\text { Non- } \\
\text { drained }\end{array}$ & Drained & $\begin{array}{c}\text { Non- } \\
\text { drained }\end{array}$ & Drained & $\begin{array}{c}\text { Non- } \\
\text { drained }\end{array}$ & Drained & $\begin{array}{c}\text { Non- } \\
\text { drained }\end{array}$ & \begin{tabular}{c} 
Drained \\
\hline $\begin{array}{l}\text { Coefficient of variance for } \\
\text { the period of 1977-1995 }\end{array}$
\end{tabular} \\
\hline
\end{tabular}

2. Swamping process. Average Ramenky moistening degree indexes display retention of considerable difference in ecologic conditions of non-drained and drained ecosystems (Tab. 3). Difference at upper level makes 3 points, so non-drained meadows fall into "damp" class and drained - on upper bound of "fresh and dry" meadows. It is interesting that moistening (as well as productivity) is higher at low level meadows within zone of drainage influence than in non-drained sites. Thereby drainage affects lower sites of catena, leveling the difference between drained marshes and wet meadows.

Polynomial fit of annual dynamics of Ramensky indexes (Fig. 4) illustrates growth of moisture in non-drained sites. The growth is especially prominent in last ten years, during which postagrogenic succession took place all over the region. By means of the same method, similar effect was established by LYURI ET AL. (2005) - reforestation of meadows and agrocoenosis is complemented by humidity growth, commonly from 3 to 12 points by Ramensky scale. 
Journal of Landscape Ecology (2011), Vol: 4 / No. 3.

Table 3: Average Ramensky indexes

\begin{tabular}{|l|c|c|c|c|c|c|c|c|}
\hline & \multicolumn{2}{|c|}{ Marshes } & \multicolumn{2}{c|}{ Low level } & \multicolumn{2}{c|}{ Middle level } & \multicolumn{2}{c|}{ Upper level } \\
\cline { 2 - 9 } & $\begin{array}{c}\text { Non- } \\
\text { drained }\end{array}$ & Drained & $\begin{array}{c}\text { Non- } \\
\text { drained }\end{array}$ & Drained & $\begin{array}{c}\text { Non- } \\
\text { drained }\end{array}$ & Drained & $\begin{array}{c}\text { Non- } \\
\text { drained }\end{array}$ & Drained \\
\hline Average humidity index & 93.1 & 91.7 & 81.4 & 85.8 & 71.0 & 69.0 & 66.4 & 63.5 \\
\hline $\begin{array}{l}\text { Average index of } \\
\text { humidity changeability }\end{array}$ & 7.6 & 8.3 & 73 & 7.2 & 7.5 & 7.9 & 7.3 & 8.1 \\
\hline $\begin{array}{l}\text { Average soil fertility } \\
\text { index }\end{array}$ & 8.7 & 9.3 & 8.6 & 8.7 & 8.6 & 8.4 & 7.9 & 8.8 \\
\hline
\end{tabular}

Fig. 4: Average Ramensky moistening degree indexes. Polynomial fit.

a. Marshes

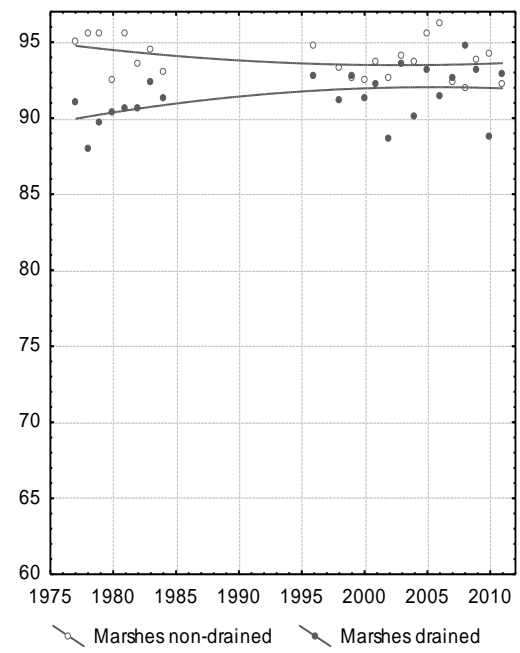

b. Low level meadows

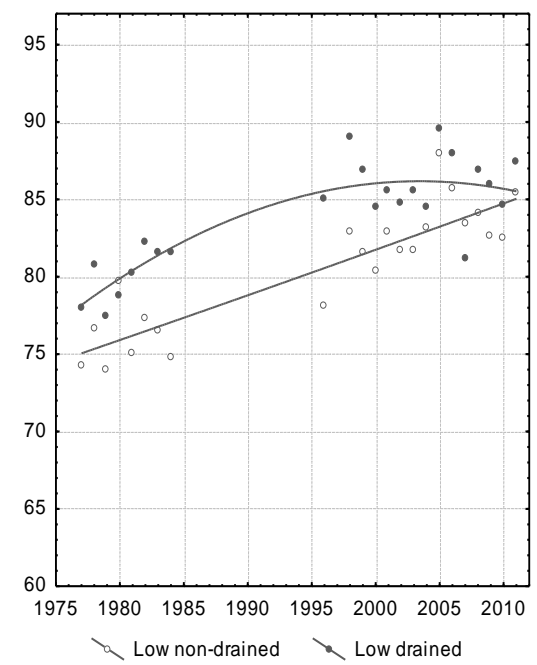

c. Middle level meadows

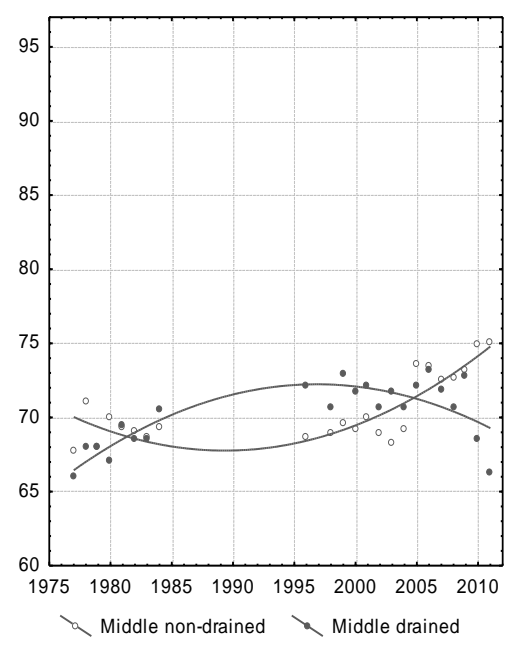

d. Upper level meadows

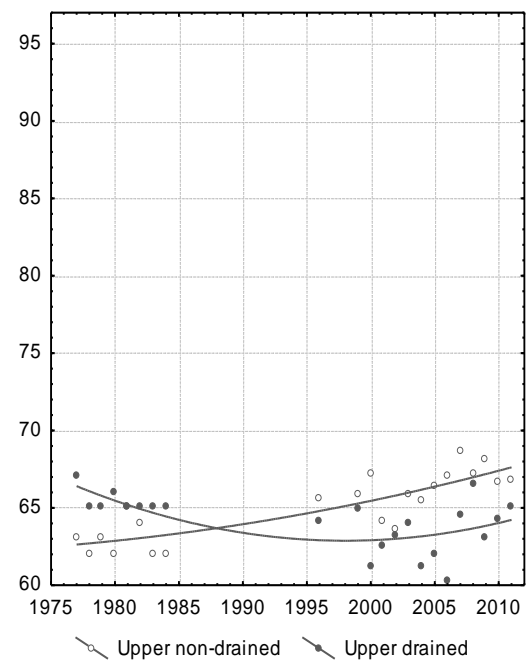


Meanwhile ecosystems in zone of drainage influence behave in different ways: upper level ecosystems follow background trend, and low level ecosystems stagnate. So the fact that upper catena levels earliest start functioning according to natural dynamics, repeat itself.

Moistening variability estimated by Ramensky scales is seasonably and annually relatively high in the whole area during the last 4 years. Ecosystems within the zone of drainage influence are more variable, especially at catena edges. Again low level meadows appear in the most favorable conditions.

3. Soil fertility assumed by soda-and-acid environment is growing in drained geosystems due to the ground water level lowering, peat decomposition and vegetation change. At background marsh sites average $\mathrm{pH}$ is around 3.5-4.0 while in drained areas it rises up to 4.5-5.0 and even higher. Similar trend was recorded by Andersen et al. (Andersen, Francez, Rochefort 2006) in Quebec region - $\mathrm{pH}$ on meliorated sites rises by 0.6-0.9 points.

Soil fertility derived by bio-indicative method is predominantly of "not rich" class in the region (Fig. 5). Type of fertility indexes distribution in non-drained geosystems is relevant to the process of slow matter outwash from upper catena levels and accumulating on low levels. Matter distribution in catena in zone of drainage influence cannot be described by natural processes and is considerably affected by man. Significant fertility growth in drained marshes is a result of $\mathrm{pH}$ growth and random additional fertilizing in period 19861993 (Авессаломова, Дьяконов 1983).

Fig. 5: Average Ramensky soil fertility index. Polinomial fit.

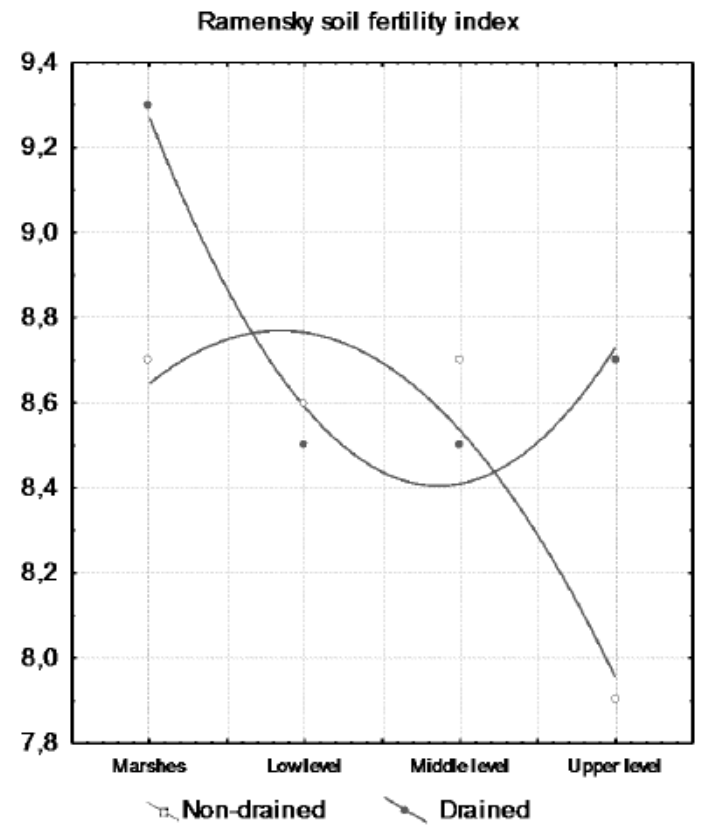

\section{CONCLUSIONS}

1. Despite relatively high soil fertility, the productivity of drained ecosystems has a trend to decrease in the last years. 
2. Growth of moisture is registered for the whole territory, while difference in moistening between sites in zone of influence and their background analogues retains significant, which proves residual efficiency of abandoned drainage works.

3. Water regime reorganization to natural mode starts from upper level geosystems.

4. Drainage influence appears to influence in the most favorable way at low level geosystems, which are more productive and their characteristics are more stable.

5. Studied postmeliorated landscapes of Central Meschera undergo an early-succession stage. Progressive swamping process not compensated by growth of restoring ecosystems productivity result in loss of environmental and reproductive functions valuable for land use. Meanwhile new socio-economic functions don't appear. Ecosystems succession may be considered as a function of nature conservation, but in Central Mescera lowland, like in many places worldwide, (Franz, Romanowski, Saavedra 2011, Uematsu et. al. 2010) succession results in biodiversity loss. Landscapes become homogeneous, difficult to traverse and unattractive for recreation. Thereby evolution of postmeliorated landscapes of Central Meschera is destructive from socio-economic standpoint, it cancels efforts and resourses spent on landscape transformation without any significant advantages for a new landscape modification.

\section{REFERENCES}

Авессаломова, И.А., Дьяконов, К.Н. (1983). Геохимические аспекты осушительной мелиорации в долинно-зандровых ландшафтах Мещеры. Вестн. Моск. Ун-та. Сер.5. География. 1983. №3. С. 46-54.

Анненская, Г.Н., Мамай, И.И. \& Цесельчук, Ю.Н. (1990). Ландшафтьь Рязанской Мещеры и возможности их освоения. М.: Изд-во Моск. Ун-та. 246 с.

Географические проблемы осушительных мелиораций (1990). 187 с.

Раменский, Л.Г. (1956). Экологическая оценка кормовых угодий по растительному покрову. Гос. изд-во сельхоз. Лит-ры. 470 с.

Andersen, R., Francez, A.-J. \& Rochefort, L. (2006). The physicochemical and microbiological status of a restored bog in Quebec: Identification of relevant criteria to monitor success. Soil Biology and Biochemistry. Vol. 38, Issue 6. 1375-1387 p.

Ellenberg, H. (2009). Vegetation Ecology of Central Europe. Cambridge University Press, 2009. $735 \mathrm{p}$.

Franz, K.W., Romanowski, J. \& Saavedra, D. (2011). Effects of prospective landscape changes on species viability in Segre River valley, NE Spain, Landscape and Urban Planning, Vol. 100, Issue 3, 15, 242-250 p.

Наука, М. (1989). Geoecological foundations of territotial planing. 144 c.

Lyuri, D.I., Goryachkin, S.V., Karavaeva, N.A., Denisenko, E.A. \& Nefedova, T.G. (2005). Dynamics of Agricultural lands of Russia in XX century and Postagrogenic Restoration of vegetation and soils. M.: GEOS, $416 \mathrm{p}$.

Millennium Ecosystem Assessment (2005). Ecosystems and Human Well-being. Synthesis Peport. - Island Press, Washington DC, 160 pp.

Uematsu, Y, Koga, T., Mitsuhashi, H. \& Ushimaru, A. (2010). Abandonment and intensified use of agricultural land decrease habitats of rare herbs in semi-natural grasslands. Agriculture, Ecosystems \& Environment, Vol. 135, Issue 4, 1. 304-309 p. 